\title{
PERLINDUNGAN HUKUM TERHADAP KONSUMEN PROPERTI SISTEM PRE PROJECT SELLING BERDASARKAN PRINSIP PERLINDUNGAN KONSUMEN DALAM UU NOMOR 8 TAHUN 1999 TENTANG PERLINDUNGAN KONSUMEN

\author{
Oleh:
}

I Made Artha Rimbawa 1

E-mail: artharimbawa5@gmail.com¹

Institusi : Fakultas Hukum Universitas Ngurah Rai

\begin{abstract}
Pre-Project Selling is an agreement made by the parties to the sale and purchase of property before the project is built and the new one is sold in the form of pictures or concepts. The reason developers develop this Pre-Project Selling practice is to find out the market's response to the property product that will be built (test the water). The Pre-Project Selling practice is a special agreement. This is because the object of the agreement is an image or concept from the developer. The rise of the Pre-Project Selling certainly presents some problems. One of them is about protecting consumers from images or concepts proposed by Developers. In this study will discuss the Consumer protection of Consumer Protection against PreProject Selling practices that refer to the legal principles in the Consumer Protection Act. This type of research is normative research, which is research based on studies that are in accordance with the theories and legal rules that have been determined. This normative research also functions to provide a juridical argument against the occurrence of emptiness, obscurity, and norm conflicts. Thus this research is considered very important as a policy input material in order to provide the value of justice for the community.
\end{abstract}

Keywords: Consumer Protection; Pre Project Selling, Consumer Protection Law

\section{Abstrak}

Pre Project Selling adalah perikatan yang dilakukan oleh penjual kepada pembeli property yang belum dibangun masih berupa gambar atau konsep. Alasan pengembang melakukan sistem Pre Project Selling adalah untuk mengetahui respon pasar atau produk property yang akan dibangun. Pre Project Selling adalah perjanjian dalam bentuk khusus. Hal ini karena objek perjanjian merupakan gambar atau konsep dari pengembang. Maraknya Pre Project Selling menimbulkan beberapa problematika. salah satunya adalah mengenai perlindungan konsumen dari gambar atau konsep yang diajukan oleh pengembang. Dalam penelitian ini akan membahas perlindungan hukum terhadap konsumen Pre Project Selling melalui prinsip perlindungan konsumen berdasarkan undang - undang nomor 8 tahun 1999, tentang perlindungan konsumen. Jenis penelitian yang digunakan adalah penelitian normatif, yaitu penelitian berdasarkan kajian yang sesuai dengan teori dan aturan hukum yang telah ditetapkan. Penelitian kekaburan dan konflik norma. Dengan demikian penelitian ini dirasa sangat penting sebagai bahan masukan kebijakan agar memberikan nilai keadilan bagi masyarakat.

Kata Kunci : Perlindungan Konsumen, Pre Project Selling, Undang Undang Perlindungan Konsumen

\section{PENDAHULUAN}

Kebutuhan pokok dalam hidup manusia terdiri dari tiga unsur utama, yaitu sandang, pangan dan papan. Abraham Harold Maslow merupakan salah seorang tokoh psikologi yang lahir di Brookolyn New York pada tahun 1908. Abraham Maslow mengembangkan model Hierarki kebutuhan dan sampai saat ini tetap 
Perlindungan Hukum Terhadap Konsumen Properti Sistem Pre Project Selling Berdasarkan Prinsip Perlindungan Konsumen Dalam Uu Nomor 8 Tahun 1999 Tentang Perlindungan Konsumen................................... (I M.A. Rimbawa., 137-148)

digunakan dalam memahami motivasi manusia. Hierarki kebutuhan dari Maslow terdiri dari kebutuhan fisik, kebutuhan keamanan, kebutuhan sosial, kebutuhan penghargaan, dan kebutuhan aktualisasi diri. (Yuliana, 2018): 349). Segala usaha dilakukan manusia untuk memenuhi kebutuhan tersebut, dan atas kebutuhan tersebut pula menjadi peluang bagi manusia lainnya dengan memberikan sarana pemenuhan kebutuhan pokok manusia dalam bentuk sebuah usaha. Usaha perdagangan dan pangan untuk memenuhi kebutuhan pangan, usaha dibidang tekstil bertujuan untuk memenuhi kebutuhan manusia akan sandang, dan kebutuhan akan papan menjadi peluang usaha bagi pengusaha perumahan yang dikenal dengan developer.

$$
\text { Pertumbuhan }
$$

penduduk bersinergi dengan bertambahnya kebutuhan akan hunian atau rumah, konsistensi minat dan kebutuhan masyarakat akan hunian yang layak dan nyaman menjadi target usaha dari perusahaan - perusahaan yang bergerak di bidang pembangunan dan pengolahan lahan yang dikenal dengan usaha pengembang properti. Istilah properti dalam Kamus Besar Bahasa Indonesia diartikan sebagai harta berupa tanah dan bangunan beserta segala sarana dan prasarana yang merupakan bagian yang tidak terpisahkan dari tanah atau bangunan tersebut, (Poerwadarminta, 2002) difinisi harta yang dimaksud dalam pengertian properti adalah berupa tempat tinggal atau hunian. Sebelum terjadinya resesi ekonomi global tahun 2015, grafik penjualan properti di Bali berada dalam titik tertinggi dimana pengusaha properti dapat sold out pejualan pada tahap pemasaran hanya dengan mengeluarkan blok plan dan brosur penjualan, dalam kondisi tanah mentah (tanah yang belum dilakukan pematangan lahan dan blok/kavling) dan rumah belum dibangun, sistem penjualan seperti tersebut disebut dengan pre project selling. Pre project selling adalah jual beli secara pesanan yang dilakukan sebelum fisik bangunan dibangun, dan properti yang dijual hanya berupa gambar atau konsep, berserta rencana tata ruang bangunan, kawasan pembangunan, daftar harga dan metode pembayaran (Simamora, 2017).

$\begin{array}{cc}\text { Developer berasal dari Bahasa } \\ \text { Inggris } & \text { berarti } \\ \text { pembangun/pengembang } & \text { Difinisi }\end{array}$
pembangun/pengembang. Difinisi tentang developer dapat ditemukan dalam Pasal 5 ayat (1) Peraturan Menteri Dalam Negeri Nomor 5 tahun 1974, yang menyebutkan bahwa developer adalah suatu perusahaan yang berusaha dalam bidang pembangunan perumahan dari berbagai jenis dalam jumlah yang besar di atas suatu areal tanah yang akan merupakan suatu kesatuan lingkungan pemukiman yang dilengkapi dengan prassarana prasarana lingkunan dan fasilitas fasilitas sosial yang diperlukan oleh masyarakat penghuninya. Dalam pasal Pasal 1 angka 15 Undang - Undang No. 20 Tahun 2011 tentang Rumah Susun, developer didifinisikan sebagai setiap orang dan/atau pemerintah yang melakukan pembangunan perumahan dan pemukiman (Salim \& Pandamdari, 2019).

Rumah menjadi kebutuhan pokok bagi sebagai besar masyarakat, berdasarkan data yang dikeluarkan oleh Menteri Pekerjaan Umum dan Perumahan Rakyat setidaknya masyarakat membutuhkan 13,5 Juta, dengan kebutuhan akan rumah baru sebesar 800-900 ribu unit dengan kemampuan pemenuhan akan kebutuhan rumah tersebut hanya mampu dipenuhi sekitar 600 ribu unit rumah per tahunnya (Suparji \& Pratamalistya, 2020). Dalam rangka memenuhi kuota tersebut para pengusaha perumahan/developer berlomba - lomba untuk menarik minat pembeli dengan berbagai strategi pemasaran, strategi penjualan yang banyak dipergunakan oleh developer adalah dengan sistem Pre Project Selling. Strategi cukup ampuh menarik 
minat pembeli karena beberapa tawaran yang diberikan oleh devpeloper seperti potongan harga, bonus pembelian berupa elektronik kebutuhan rumah termasuk juga dengan kemudahan dalam metode pembayaran yang dapat dilakukan secara bertahap berdasarkan kemampuan membayar dari pembeli atau dengan kesepakatan sampai rumah jadi. Pre Project Selling adalah sebuah sistem pemasaran dalam penjualan rumah yang dilakukan dalam kondisi rumah belum terbangun, masih berupa gambar dan perencanaan pembangunan (Adjie, Juni 2020). Mekanisme pemasaran dengan Pre Project Selling dilakukan dengan menawarkan unit rumah atau hunian yang dapat berupa apartemen, rumah susun dan lain-lain, berdasarkan brosur yang berisi konsep hunian, rancangan bangunan, luas hunian, lokasi, sarana prasaranan, fasilitas dan keunggulan dari unit yang ditawarkan (Putra, 2019).

Mekanisme transaksi jual beli properti yang dilakukan pada saat tanah mentah dan belum ada pembangunan adalah dengan pengikatan pendahuluan yang dapat dilakukan di bawah tangan atau dengan akta notaris berupa Akta Pengikatan Perjanjian Jual Beli (PPJB). Penjualan properti dengan pola PPJB adalah gairah bagi pengusaha pengembang karena mendapatkan suntikan dana langsung dari masyarakt yang dapat digunakan sebagai modal pembangunan, sehingga pengusaha properti dapat meminimalisasi pinjaman dari Bank sebagai modal usaha.

Perjanjian permulaan ini menjadi sah karena berdasarkan Keputusan Menteri Perumahan Rakyat No. 9/KPTS/M/1995 Tahun 1995 tentang Pedoman Pengikatan Jual Beli Rumah, Peraturan Menteri ini bertujuan untuk melindungi pengusaha properti dan konsumen dari kemungkinan - kemungkinan terjadinya cidera janji dari salah satu pihak. Keputusan Menteri ini sebagai bentuk perlindungan hukum terhadap kedua belah pihak, terutama dengan keputusan Menteri ini dimungkinkan kepada pengusaha properti untuk melakukan penjualan terlebih dahulu terhadap unit properti sebelum properti tersebut dibangun.

Diantara kemudahan dan tawaran - tawaran yang diberikan dalam pembelian rumah dengan sistem Pre Project Selling, si satu sisi akan memberikan keuntungan bagi pembeli dan sisi lain akan memberikan keuntungan secara finansial bagi developer, karena sistem Pre Project Selling developer dapat mengambil modal kerja di awal dari konsumennya. Dibalik keuntungan tersebut ada potensi terjadinya permasalahan permasalahan hukum yang dapat mengakibatkan kerugian khusunya kepada pembeli hunian yang disebut dengan konsumen. Permasalahan yang paling sering terjadi adalah terkait keabsahan perijinan, kepemilikan atas tanah dan kemungkinan perubahan fisik dan peruntukan dari tanah yang akan dijadikan tempat pembangunan. Sebagai pembeli yang cerdas konsumen perumahan setidaknya memperhatikan beberapa hal sebelum membeli yaitu, legalitas pengusaha developer termasuk ijin usahanya, kepastian lokasi perumahan, legalitas penguasaan lahan yang akan di bangun dan aspek - aspek hukum lainnya. Dalam situasi yang tidak menguntungkan bagi konsumen perumahan, aspek hukum yang dapat memberikan perlindungan hukum dan sebagai paying payung hukum terhadap konsumen perumahan adalah dengan mengacu pada Undang - Undang Nomor 8 Tahun 1999 tentang Perlindungan Konsumen, dalam undang - undang tersebut telah mengatur bahwa hak dasar dari konsumen hak atas kenyamanan, keamanan dan keselamatan dalam mengkonsumsi barang dan/atau jasa dan hak untuk memilih baran dan/atau jasa serta mendapatkan barang dan/atau jasa tersebut. 
Perlindungan Hukum Terhadap Konsumen Properti Sistem Pre Project Selling Berdasarkan Prinsip Perlindungan Konsumen Dalam Uu Nomor 8 Tahun 1999 Tentang Perlindungan Konsumen................................... (I M.A. Rimbawa., 137-148)

Dalam prinsip perlindungan konsumen, tindakan penjual/developer yang berpotensi menimbulkan kerugian kepada konsumen pembeli dengan sistem Pre Project Selling dengan adanya undang - undang perlindungan konsumen dapat dikenai sanksi, dimana konsumen berhak untuk menuntut ganti rugi kepada developer. Rumusan permasalahan yang dikaji dalam penelitian ini adalah perjanjian dalam sistem Pre Project Selling dan perlindungan konsumen dalam perjanjian dalam sistem Pre Project Selling. Penelitian ilmiah ini diangkat dengan judul Perlindungan Hukum Terhadap Konsumen Properti Sistem Pre Project Selling Berdasarkan Prinsip Perlindungan Konsumen Dalam UU Nomor 8 Tahun 1999 Tentang Perlindungan Konsumen

\section{METODE}

Penelitian ini menggunakan metode penelitian yuridis normative dengan pendekatan undang - undang (P.M, 2010), yaitu undang - undang No. 8 Tahun 1999 tentang perlindungan konsemen, yuridis normatif merupakan sebuah penelitian yang menjadikan norma hukum sebagai objek dalam penelitian (Diantha, 2016). Bahan hukum yang dipergunakan dalam penelitian ini adalah bahan hukum primer (peraturan perundang-undangan) dan sekunder yang diperoleh dari literatur, karya ilmiah dan doktrin.

\section{PEMBAHASAN}

Analisis bisnis yang mendasari pengembang perumahan/ developer menggunakan metode penjualan Pre Project Selling bertujuan untuk menguji respon pasar atas produk property yang akan dibangun (Hidayah, 2019). Dengan strategi pemasaran Pre Project Selling pengembang properti dapat memanfaatkan pembayaran yang dilakukan oleh konsumen sebagai modal dalam melakukan pembangunan, dengan konsep awal adalah kepercayaan yang bangun sejak awal diantara pembeli dan penjual, dimana penjual percaya bahwa pembeli akan melunasi pembeliannya begitupun pembeli memiliki keyakinan bahwa penjual akan menyelesaikan pembangunan dan meberikannya kepada pembeli (Purbandari, 2012).

Menurut Erwin Kallo (Estate, 2006), kata kunci yang harus dipegang dalam pembelian propertiy dengan sistem Pre Project Selling adalah :

a. Cek legalitas proyek, pengecekan ini meliputi pengecekan sertifikat atau akta jual beli tanah, surat ijin atau akta pengusaan terhadap tanah, termasuk ijin-ijin prinsip dan ijin mendirikan bangunan.

b. Pastikan bahwa harga penjualan projek Pre Project Selling lebih murah dari harga setelah rumah jadi.

c. Peninjauan lokasi projek, dengan segala sarana dan prasarana penunjang termasuk fasilitas fasilitas yang dibutuhkan.

d. Memastikan kelayakan dalam menerima kredit, dimana seorang konsumen property sebaiknya lebih dahulu mengecek atau melakukan Analisa kelayakan kredit di Bank, tentang kemapuan membayar dan kondisi keuangan sehingga pembelian dengan kredit menjadi aman.

e. Membuat kesepakatan dengan developer terkait jangka waktu pembangunan dan tahap pembayaran untuk pembelian dengan pembayaran bertahap.

f. Mempelajari dan memeriksa setiap isi perjanjian, demi kepastian dan perlindungan hukum bagi kedua belah pihak agar tidak hanya menguntungkan salah satu pihak saja.

Prinsip dalam pembangunan propertiy pada setiap daerah adalah sama (Properti, 2005), yang membedakanya adalah sistem birokrasi dan administrasi secara teknis, yang secara garis besar terkait 
perijinan yang harus dilengkapi adalah ijin prinsip (ijin lokasi atau surat ijin penunjukan penggunaan dan penguasaan lahan dari instansi terkait), Site Plan (peta atau denah lokasi yang dibuat oleh developer yang telah disahkan oleh dinas tata ruang dan badan pertanahan kabupaten/kota) dan ijin mendirikan bangunan (IMB).

Teknis yang terjadi dilapangan, Pre Project Selling dilakukan sebelum hal - hal tersebut diatas dilakukan, dengan tidak diselesaikannya perijinan dasar tersebut diawal telah memberikan potensi terjadinya masalah kepada konsumen dan pelanggaran terhadap undang undang yang berlaku. Potensi resiko kerugian yang terjadi pada konsumen adalah (Nola, 2017):

1. Tidak dilaksanakanya apa yang telah dijanjikan oleh perusahaan pengembang/developer.

2. Apa yang dijanjikan dilakukan tidak tepat waktu (terlambar).

3. Dilaksanakan perjanjian hanya sebagian atau tidak sesuai denga napa yang telah diperjanjikan.

4. Dilakukan hal-hal yang tidak semestinya, yang tidak perbolehkan untuk dilakukan dalam perjanjian tersebut.

Dalam data yang dikeluarkan oleh Yayasan Lembaga Konsumen Indonesia (YLKI), system Pre Project Selling rentan menimbulkan masalah, dimana sejak tahun 2014 YLKI setidaknya telah menerima 440 pengaduan terhadap developer akibat Tindakan developer yang tidak konsisten denga napa yang telah diperjanjikan, dengan tawaran dan janji promosi yang diberikan diawal. Ketidak jelasan informasi, komintmen dalam pembangunan dan realisasi terhadap fasilitas yang ditawarkan diawal berbeda dengan yang terrelisasi di lapangan (Nola, Permasalahan Hukum Dalam Praktik Pre Project Selling Apartemen, 2017). Aturan mengenai Pre Project Selling terdapat dalam ketentuan Pasal 42 ayat (2) Undang - Undang Nomor 1 tahun 2011 tentang Perumahan dan Kawasan Pemukiman, yang menyebutkan bahwa :

Perumahan yang masih dalam proses pembangunan, dapat dipasarkan melalui sebuah system yang dilakukan dengan perjanjian pendahuluan setelah terlebih dahulu harus terpenuhinya syarat - syarat tentang kepastian status pemilikan tanah, tentang hal - hal yang diperjanjikan, mengenai kepemilikan ljin Membangung (IMB) induk, ketersediaan sarana dan prasarana dan utilitas umum, serta keterbangunan perumahan paling sedikit $20 \%$.

Dari apa yang disebutkan dalam pasal tersebut diatas, ada beberapa unsur yang harus dipenuhi dalam melakukan penjualan property dengan sistem Pre Project Selling, yaitu :

1. Perjanjian Pendahuluan

Perjanjian adalah dimana dua orang atau lebih melakukan sebuah perbuatan hukum dengan mengikatkan diri satu dengan lainnya dalam bentuk sebuah perjanjian (Masjchoen, 2007). Dalam membuat perjanjian para pihak diberikan kebebasan untuk menentukan isi dari perjanjian tersebut yang dibatasi dengan pengaturan dalam Pasal 1337 BW dengan ketentuan yang diatur dalam Pasal 1320 BW. Ketentuan tersebut berlaku pula dalam pembuatan perjanjian terkait system penjualan property dengan system Pre Project Selling.

Sebelum melakukan PPJB, telebih dahulu akan dilakukan penandatanganan Surat Pesanan (SP) yang dilakukan berbarengan dengan pembayaran tanda jadi.

2. Kepastian Status Kepemilikan atau Penguasaan Lahan

3. Ijin Mendirikan Bangunan (IMB) Induk

IMB adalah bentuk pengawasan yang dilakukan oleh pemerintas daerah dengan menetapkan aturan bahwa setiap bangunan yang dibangun wajib memiliki ijin mendirikan bangunan agar tata bangunan yang 
Perlindungan Hukum Terhadap Konsumen Properti Sistem Pre Project Selling Berdasarkan Prinsip Perlindungan Konsumen Dalam Uu Nomor 8 Tahun 1999 Tentang Perlindungan Konsumen................................... (I M.A. Rimbawa., 137-148)

akan dibangun sesuai dengan rencana tata ruang daerah, sehingga tata bangunan tententukan sedemikian rupa secara sinergi dan teratur.

4. Tersedianya sarana dan prasarana umum

5. Keterbangunan perumahan minimal $20 \%$

Perjanjian dalam jual beli dengan system Pre Project Selling terdiri dari beberapa tahapan yaitu :

1) Pembayaran tanda jadi/pemesanan (booking fee)

pada saat penanatangan surat pesanan konsumen diminta untuk melakukan pembayaran uang pesanan (booking fee) dan uang muka (dwon payment). Dalam tahapan ini, konsumen dapat memilih unit property yang diinginkan dan dimungkinkan untuk menentukan tata ruang dan model yang diinginkan berdasarkan kesepakatan awal ini.

2) Penandatanganan Perjanjian Pengikatan Jual Beli (PPJB)

Tahapan selanjutnya setelah pemesanan yang dibuat dengan surat pesanan, adalah konsumen diminta untuk memenuhi pembayaran uang muka pembelian rumah minimal 30\% dari harta yang disepakati. Saat angka $30 \%$ ini telah terpenuhi akan dilakukan sebuah akta Perjanjian Pengikatan Jual Beli yang didalamnya memuat tentang hak - hak dan kewajiban dari penjual dan pembeli, umumnya akta ini dibuat dihadapan notaris dengan biaya yang telah dibebankan dalam harga properti (Sumardjono, 2001).

PPJB adalah sebuah perjanjian yang bersifat obligatoir, yaitu perjanjian telah dianggap sah dan mengikat hanya terbatas pada hak dan kewajiban tetapi belum terjadi perpidahan hak milik terhadap objek yang diperjanjikan, untuk dapat melakukan perpindahan hak diperlukan perjanjian lain yang disebut (zakelijke overeenkomst)/perjanjian kebendaan untuk dapat dilakukan penyerahan (levering) sebagai bentuk realisasi pemindahan hak milik( (Faudy, 1999). Mekanisme dalam penentuan hak dan kewajiban para pihak dalam transaksi Pre Project Selling dituangkan dalam sebuah Perjanjian Pengikatan Jual Beli (PPJB) (Simamora, 1996). PPJB adalah sebuah perjanjian yang bersifat obligatoir, yaitu perjanjian telah dianggap sah dan mengikat hanya terbatas pada hak dan kewajiban tetapi belum terjadi perpidahan hak milik terhadap objek yang diperjanjikan, untuk dapat melakukan perpindahan hak diperlukan perjanjian lain yang disebut (zakelijke overeenkomst)/perjanjian kebendaan untuk dapat dilakukan penyerahan (levering) sebagai bentuk realisasi pemindahan hak milik( (Faudy, 1999).

Pengikatan Perjanjian Jual Beli sebagai kesepakatan awal jual beli antara pembeli properti (konsumen) dengan penjual (pengusaha properti) memang tidak diatur dalam KUHPerdata, tetapi Undang - Undang No. 1 tahun 2011 tentang Perumahan dan Pemukiman dalam Pasal 42 ayat (1) telah mengaturnya dengan menyebutkan bahwa pembelian rumah tunggal, rumah deret, dan/atau rumah susun yang masih dalam tahap pembangunan dapat dipasarkan melalui sistem perjanjian pendahuluan jual beli sesusai dengan peraturan perundang - undangan. Dalam situasi yang baik, PPJB sebagai perjanjian pendahuluan dapat berubah kedudukanya menjadi perjanjian Jual Beli yang dituangkan dalam sebuah Akta otentik apabila :

1. Pembangunan rumah telah selesai dibangun dan siap untuk serah terima kunci untuk dapat dihuni oleh konsumen;

2. Konsumen sebagai pembeli telah melakukan pelunasan pembelian property secara seluruh dan penuh, termasuk terhadap kewajiban atas pajak - pajak dan biaya - biaya lain yang terkait dengan proses tersebut. Mengenai biaya - biaya dan pajak pembelian umumnya berdasarkan perhitungan dari notaris;

3. Proses permohonan hak guna (untuk rumah susun) atas tanah telah selesai sehingga terbit sertifikat Hak 
Guna Bangunan (HGB), dan untuk rumah tinggal atau rumah deret akan terbit sertifikat Hak Milik (SHM) atas nama perusahaan property yang kemudian dibalik nama kepada konsumen, saat proses ke dua telah selesai dilakukan.

Sebagai dasar hukum mengapa dalam proses PPJB maupun AJB sebuah perjanjian jual beli properti dilakukan dengan dituangkan dalam sebuah akta adalah mengacu pada ketentuan Pasal 616 KUHPerdata menyebutkan bahwa peralihan kepemilikan terhadap tidak bergerak dilakukan dengan cara penguman akta. Properti berupa rumah/hunian dikatagorikan sebagai benda tidak bergerak karena dalam peralihanya didahului dengan proses balik nama sebuah akta otentik dan tidak dilakukan secara serta merta sebagaiman pengalihan hak atas benda bergerak seperti kendaraan dan logam mulia. Seperti pada umumnya setiap peristiwa hukum, transaksi jual beli properti yang dilakukan dengan PPJB sebagai pendahuluan menimbulkan resiko, baik bagi pengusaha properti sebagai penjual maupun bagi konsumen. Adapun resiko yang mungkin terjadi adalah :

1. Resiko terjadinya wanprestasi oleh penjual, dimana penjual tidak menyelesaikan pembangunan property sebagaimana yang diperjanjikan diawal,

2. Resiko terjadinya pailit dari perusahaan properti yang diakibatkan ketidak mampuan membayar utang kepada krediturnya.

3. Penandatanganan Akta Jual Beli

Tahap penandatanganan Akta Jual Beli adalah tahapan terakhir dalam transaksi jual beli properti, termasuk jual beli yang dilakukan dengan metode pre project selling. Dimana dalam tahapan ini kedua belah pihak (penjual dan pembeli) sama - sama telah melakukan prestasi sebagaimana yang telah disepakati dalam PPJB, penjual telah menyelesaikan pembangunan properti sesuai yang disepakati, dengan telah melengkapi ijin - ijin yang diperlukan dan pembeli telah melakukan pelunasan terhadap pembelian properti, memenuhi kewajiban membayar pajak - pajak dan biaya biaya dalam prose jual beli. Proses AJB dilakukan dihadapan Pejabat Pembuat Akta Tanah (PPAT) dan biasanya bersamaan dengan serah terima kunci rumah. (Agustining \& Yusrizal).

4. Penandatanganan Berita Acara Serah Terima Rumah

Penandatanganan berita acara serah terima rumah umumnya dilakukan bersamaan dengan penandatanganan akta jual beli, dimana developer akan menyerahkan rumah kepada konsumen yang sebelumnya dicek terlebih dahulu oleh konsemen tersebut mengenai kelengkapan sebagaimana yang telah diperjanjikan di awal.

Kecenderungan munculnya masalah dalam jual beli properti dengan pre project selling adalah sampai pada tahapan PPJB, dimana penjual tidak memenuhi prestasinya untuk melakukan pembangunan rumah terkait dengan tidak terpenuhinya modal pembangunan dan terlilit beban hutang bank atas jaminan yang diagungkan adalah proyek properti yang diperjual belikan. Saat developer tidak mampu melakukan prestasinya maka akan menjadi sebuah peristiwa hukum yang disebut dengan wanprestasi. Wanprestasi atau cidera jandi adalah peristiwa dimana prestasi atau kewajiban yang dijanjikan akan dilakukan tidak dilakukan baik sebagain atau seluruhnya sebagaimana yang telah disepakati dalam perjanjian tersebut (Adati, 2018) yakni sama sekali tidak memenuhi isi perjanjian, terlambat dalam memenuhi perjanjian atau keliru atau tidak memenuhi isi perjanjian.

Sebuah kesepakatan yang dituangkan dalam akta perjanjian menimbulkan hak dan kewajiban bagi masing - masing pihak, peristiwa 
Perlindungan Hukum Terhadap Konsumen Properti Sistem Pre Project Selling Berdasarkan Prinsip Perlindungan Konsumen Dalam Uu Nomor 8 Tahun 1999 Tentang Perlindungan Konsumen................................... (I M.A. Rimbawa., 137-148)

dimana developer wanprestasi maka ada konsumen yang akan dirugikan, kerugian terhadap konsumen ini memerlukan payung hukum untuk melindungi hak - hak dari konsumen. Shidarta menyebutkan, perlindungan konsumen adalah segala daya dan upaya yang dilakukan untuk menjamin adanya kepastian hukum dalam memberikan perlindungan kepada konsumen sebagai pembeli yang beritikad baik (Shidarta, 2000). Kedudukan yang tidak seimbang dalam PPJB jual beli property dengan sistem pre project selling terjadi, dimana developer memiliki kedudukan yang lebih tinggi dari konsumenya, karena klausula baku yang terdapat dalam PPJB dibuat oleh developer sehingga konsumen tidak memiliki pilihan untuk bernegosiasi atas klausula tersebut (Muhammad, 1992). Klausula baku dalam PPJB antara developer dengan konsumen dituangkan dalam sebuah perjanjian yang berbentuk kolom isian dimana konsumen cukup mengisi kolom-kolom kosong yang umumnya berisikan identitas konsumen sebagai pembeli, kemampuan membayar dan jumlah penghasilan dari konsumen.

$$
\text { Pasal } 18 \text { Undang - Undang }
$$

Perlindungan Konsumen telah melarang dengan tegas mengenai pencantuman klausula baku pada setiap dokumen atau penyampaian yang tujuannya adalah merugikan konsumen, dalam ayat (3) disebutkan dengan tegas bahwa segala dokumen yang didalamnya memuat klausula baku yang tidak memenuhi ketentuan dalam ayat (1) dan (2) pasal ini, maka perjanjian tersebut dinyatakan batal demi hukum (Suparji \& Pratamalistya, 2020). Rajeswari Kaniah dan Anwar Fazal yang dikutip oleh Yusuf Sofie menyebutkan, bahwa dalam prakteknya penggugaan klausula baku sering kali mencantumkan klausula pengecualian atau exemption clause, seperti penjatuhan denda kepada konsumen apabila terjadi keterlambatan dalam pembayaran angsuran,tetapi tidak berlaku sanksi kepada developer apabila melakukan keterlambatan dalam melakukan penyerahan unit (Shofie, 2000).

Pembelian rumah dengan sistem pre project selling memerlukan serangkaian proses administrasi yang harus dipenuhi, yaitu dimulai dengan Surat Pesanan (SP), Perjanjian Pengikatan Jual Beli (PPJB), Berita Acara Serah Terima Rumah (BAST/Hand Over) terakhir adalah proses Akta Jual Beli (AJB). Terdapat kelemahan - kelemahan dalam jual beli rumah dengan metode pre project selling, yaitu :

1. Tidak adanya kepastian pembangunan dan serah terima rumah, karena sejak awal konsumen tidak akan mendapatkan jaminan baik berupa SHM tanah maupun legalitas dari bangunan seperti IMB;

2. Realisasi Refund, umumnya terjadi pada pembelian yang dilakukan dengan carat unai atau tunai bertahap. Dalam posisi ini konsumen terancam tidak akan mendapatkan pengembalian secara penuh atau diikuti dengan pemotongan pemotongan administrasi yang dilakukan secara sepihak oleh pengusaha pengembang. Kesepakatan pemotongan pembayaran saat terjadi pembatalan pembelian rumah biasanya telah disepakati di awal pada saat penandatanganan surat pesanan.

3. Ketidak pastian serah terima unit yang sudah dibeli., Hal ini terjadi karena umumnya pengusaha akan memenuhi target penjualanya terlebih dahulu sebelum melakukan pembangunan, pembangunan rumah yang dibeli dengan metode pre project selling umumnya dilakukan dengan dana yang diterima dari pembeli untuk mengurangi pinjaman modal dari bank, karena dianggap memiliki resiko yang lebih rendah.

Undang - Undang Perlindungan Konsumen Nomor 8 Tahun 1999 telah menjadi payung hukum bagi konsumen properti dengan sistem pembelian pre project selling.. Dalam Undang-undang tersebut terdapat 
beberapa asas yang dapat digunakan sebagai pedoman, yaitu :

1. Asas Manfaat

Pasal 2 Undang - Undang Perlindungan Konsumen Nomor 8 Tahun 1999 mengamanatkan bahwa segala upaya dalam penyelenggaraan perlindungan terhadap konsumen harus dapat memberikan manfaat kepada konsumen dan pelaku usaha.

2. Asas Keadilan

Dalam jual beli properti dengan pre project selling, berdasarkan asas keadilan yang diamanatkan oleh Undang-Undang Perlindungan Konsumen Nomor 8 Tahun 1999 bukan dalam artian bahwa hanya konsumen yang harus dilindungi dan mendapatkan keadilan, dimana diberikan kesempatan yang sama kepada penjual untuk memperoleh keadilan sesuai dengan apa yang diperjanjikan berdasarkan hak dan kewajibanya masing - masing.

3. Asas Keseimbangan

Keseimbangan yang diharapkan dalam jual beli properti dengan pre project selling adalah adanya keseimbangan atas kepentingan diantara masing-masing pihak, yang dalam hal ini bukan hanya pembeli dan penjual tetapi masuk unsur pemerintah didalamnya. Kepentingan semua pihak harus diperhatikan secara materiil dan non materiil.

4. Asas keamanan dan

Keselamatan

Asas keamanan dan

keselamatan dimaksudkan untuk memberikan jaminan rasa aman kepada para pihak yang terkait dalam jual beli properti dengan system pre project selling, dimana pembeli akan merasa aman dengan uangnya yang telah dibayarkan dan keyakinan untuk mendapatkan hak atas propertiy yang dibelinya, sebaliknya penjual akan meyakini bahwa pembeli akan melunasi propertiy yang dibeli sehingga akan dapat menutup segala biaya yang telah dikeluarkan dan mendapatkan keuntungan dari penjualan tersebut.

5. Asas Kepastian Hukum
Kepastian hukum adalah faktor yang paling penting dalam setiap peristiwa hukum, dalam kaitan ini dimana para pihak akan mentaati peraturan hukum yang berlaku di Indonesia sehingga negara Negara akan menjamin kepastian hukum terhadap semua warga negaranya termasuk dalam transaksi pre project selling.

Penjual dan pembeli sama sama harus berhati-hati dalam menjalankan perannya masing masing. Sangat penting menjaga keamanan diri sendiri dalam setiap transaksi apalagi transaksi yang dilakukan atas kebendaan yang belum dapat dilakukan peralihan hak diawal seperti transaksi pre project selling. Permasalahan hukum antara developer dengan konsumen dapat dilakukan dengan dua jalur penyelesaian sengketa yaitu :

1. Penyelesaian sengketa dengan litigasi

Penyelesaian sengketa dengan litigasi dilakukan dengan menempuh jalur hukum dengan mengajukan gugatan kepangdilan atau sengketa dibawa ke "meja hijau" (Fitriani, 1996). Pada prinsipnya setiap konsumen yang merasa dirugikan dapat mencari keadilan dengan melalukan gugatan ke pengadilan negeri, penyelesaian sengketa terhadap konsumen yang dilakukan melalui pengadilan dapat merujuk pada pasala 45 undang undang perlindungan konsumen (Udiana, 2011).

2. Penyelesaian sengketa Non Litigasi

Dalam Pasal 1 angka (10) Undang-undang Nomor 30 Tahun 1999 tentang Arbitrase dan alternatif Penyelesaian Sengketa, alternatif penyelesaian sengketa adalah Lembaga yang berwenang dalam membantu menyelesaikan sengketa berdasarkan kesepakatan dari para pihak yang dilakukan di luar pengadilan denga cara konsultasi, negosiasi, mediasi, konsiliasi atau penilaian ahli (Raffles, 2010). Ketentuan tentang tata cara 
Perlindungan Hukum Terhadap Konsumen Properti Sistem Pre Project Selling Berdasarkan Prinsip Perlindungan Konsumen Dalam Uu Nomor 8 Tahun 1999 Tentang Perlindungan Konsumen................................... (I M.A. Rimbawa., 137-148)

penyelesaian sengketa konsumen diatur dalam pasal 15 Surat Keputusan Menperindag Nomor 350/MPP/Kep/12/2001 tanggal 10 Desember $2001 \quad$ tentanga Pelaksanaan Tugas dan Wewenang Badan Penyelesaian Sengketa Konsumen (BPSK). Tata cara penyelesaian sengketa konsumen berdasarkan surat keputusan tersebut adalah :

1. Melalui konsiliasi

Pasal 1 angka 9 Surat Keputusan Menperindag Nomor 350/MPP/Kep/12/2001, mendifiniskan konsiliasi adalah proses penyelesaian sengketa konsumen diluar pengadilan dengan BPSK sebagai perantara, dengan mempertemukan konsumen dengan penjual di luar pengadilan dan menyerahkan cara penyelesaian kepada kesepakatan para pihak yang bersengketa. Prinsip dasar dalam konsiliasi adalah perdamaian, sebagaimana yang diatur dalam pasal 1851 sampai pasal 1864 KUHPerdata (Halomoan \& Sitong , 2016).

\section{Mediasi}

Pasal 1 angka 10 Surat Keputusan Menperindag Nomor 350/MPP/Kep/12/2001, menyebutkan mediasi adalah proses penyelesaian sengketa konsumen di luar pengadilan dan BPSK berperan sebagai mediator dalam menyelesaikan sengketa, dan hasil akhirnya diserahkan kembali kepada para pihak. Peran utama mediator adalah memantapkan garis garis dan batasan - batasan dalam bermediasi (line of communication and dialogue) diantara para pihak untuk mendapatkan kesepahaman bersama (greater mutual understanding) (Bhakti, 2019).

\section{Arbitrase}

Penetapan

penyelesaian sengketa dengan arbitrase akan dituangkan dalam perjanjian arbitrase, dimana dengan perjanjian tersebut maka para pihak akan kehilangan hak nya untuk mengajukan penyelesaian sengketa ke Pengadilan Negeri (Halomoan \& Sitong , 2016). Arbitrase menjadi metode penyelesaian sengketa konsumen dalam permasalahan yang termasuk dalam keperdataan (civil matters) atas dasar persetujuan dan kesepakatan kedua belah pihak, memiliki kekuatan mengikat (bidnding) dan dapat ditegakkan atau dilaksanakan sebagai sebuah perjanjian (Subekti, 1992).

Perlindungan hukum terhadap konsumen properti dengan sistem pre project selling dalam aturannya telah dilindungi oleh peraturan perundang undangan. Mulai dari pengaturan tentang proses PPJB di dalam KUHPerdata dan Undang - Undang Nomor 1 tahun 2011 tentang Perumahan dan Kawasan Pemukiman, . Pada peraturan perundangan tersebut diatur bahwa sejak perjanjian harus dilakukan berdasarkan ketentuan undang undang yang berlaku, . pula saat terjadinya sengketa antara konsumen dengan developer, UU Perlindungan Konsumen memberikan perlidungan dan hak untuk mendapatkan ganti kerugian terhadap kerugian yang diderita oleh konsumen akibat perbuatan developer. Unsur utama kerugian tersebut adalah akibat developer yang melakukan wanprestasi. Hanya saja yang menjadi kelemahan dalam penjualan properti dengan pre project selling yang rentan menimbulkan sengketa yang dapat melemahkan kedudukan konsumen adalah klausula baku yang diberlakukan dalam PPJB .

\section{PENUTUP}

Undang - Undang Perlindungan Konsumen Nomor 8 Tahun 1999 telah mengatur dengan jelas perlindungan hukum kepada konsumen properti dengan siystem pre project selling, dengan adanya ketentuan dalam Undang - undang tersebut konsumen dibenarkan untuk mendapatkan ganti kerugian atas perbuatan developer sebagai penjual atas putusan pengadilan maupun berdasarkan kesepakatan bersama berdasarkan penyelesaian sengketa yang dilakukan di luar pengadilan oleh Badan 
Penyelesaian Sengketa Konsumen (BPSK) dengan tiga acara yaitu konsiliasi, mediasi dan arbitrase. Lemahnya kedudukan konsumen yang menyebabkan rentan timbul sengketa antara konsumen dan developer , karena adanya klausula baku. KUHPerdata mencantumkan asas tentang kebebasan berkontrak tetapi asas tersebut memelukan batasan untuk menghindari sengketa.

\section{DAFTAR PUSTAKA}

Diantha, I. P. (2016). Metodelogi Penelitian Hukum Normatif Dalam Judifikasi Teori Hukum. Jakarta: Prenada Media Group.

Faudy, M. (1999). Hukum Kontrak ( Dari Sudut Pandang Hukum Bisnis). Bandung: Citra Aditya Bakti.

Masjchoen, S. S. (2007). Hukum Jaminan Di Indoneisa, Pokok Pokok Hukum Jaminan dan Jaminan Perorangan. Yogyakarta: Liberty.

P.M, M. (2010). Penelitian Hukum. Jakarta: Kencana.

Poerwadarminta. (2002). Kamus Besar Bahasa Indonesia. Jakarta: Balai Pustaka.

Muhammad, A. (1992). Perjanjian Baku Dalam Praktek Perusahaan Perdagangan. Bandung: PT. Citra Aditya Bakti.

Shidarta. (2000). Hukum Perlindungan Konsumen. Jakarta: Grasindo.

Shofie, Y. (2000). Perlindungan Konsumen dan Instrumen Instrumen Hukumnya. Bandung: PT. Citra Aditya Bakti.

Simamora, Y. S. (1996). Penerapan Prinsip Caveat Vendor Sebagai Sarana Perlindungan Bagi Konsumen Perumahan Di Indonesia. Universitas Arilangga.

Simamora, Y. S. (2017). Penegakan Hukum Pada Bisnis Properti Dengan Pola pre project selling . Law Journal, Fakulty of Law Universitas Airlangga Surabaya, 1.
Subekti.

(1992).

Arbitrase Perdagangan. Bandung: BPHN dan Binacipta.

Sumardjono, M. S. (2001). Kebijakan Pertanahan Antara Regulasi dan Implementasi. Jakarta: Buku Kompas.

JURNAL

Adati, M. A. (2018). Wanprestasi Dalam Perjanjian Yang Dapat Di Pidana Menurut Pasal 378 Kitab Undang - Undang Hukum Pldana. Lex Privatum, Vo.VI/No.4/Jun/2018.

Adjie, H. (Juni 2020). Pengendalian Asas Kebebasan Berkontrak Dalam Sistem Pre Project Selling. Jurnal Supremasi Hukum Magister Kenotariatan Unversitas Narotama, Vol.9. No. 1.

Bhakti, R. T. (2019). Perlindungan Hukum Konsumen Properti Atas Sistem Pre Project Selling Di Kota Batam. Jurnal Cahaya Keadilan, Volume 7, Nomor 1.

Estate, M. (2006, maret 3). Agar Tidak Terjebak Presale. Volume 3.

Fitriani, R. (1996). Penyelesaian Sengketa Lahan Hutan Melalui Proses Mediasi di Kabupaten Siak. Jurnal Imu Hukum, Volume 3, No. 1.

Hidayah, Y. W. (2019). Kepastian Hukum Hak - Hak Konsumen Dalam Transaksi Jual Beli Properti Dengan Sistem Pemasaran Pre Project Selling di Perumahan The Emerald Malang. Jurusan Hukum Bisnis Syariah, Fakultas Syariah, Universitas Islam Negeri Maulana Malik Ibrahim.

Nawi, H. S. (Juni 2018). Hak dan Kewajiban Konsumen Menurut UU No. 8 Tahun 1999 tentang Perlindungan Konsumen. Pleno De Jura, Vol. 7 No.1.

Nola, L. F. (2017). Permasalahan Hukum Dalam Praktik Pre Project Selling Apartemen. Info Singkat. 
Perlindungan Hukum Terhadap Konsumen Properti Sistem Pre Project Selling Berdasarkan Prinsip Perlindungan Konsumen Dalam Uu Nomor 8 Tahun 1999 Tentang

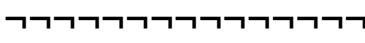

. Permasalahan Hukum Dalam Pre Project Selling. Majalah Info Singka Hukum, Vol. IX No. !8/II/Puslit/September2017.

Properti, B. (2005, Juni). Peryaratan Pengembang Properti. Nomor 22, p. 166.

Purbandari. (2012). Kepatian Dan Perlindungan Hukum Pada Pemasaran Properti Dengan Sistem Purbandari, 'Kepastian Dan Perlindungan Hukum Pada Pemasaran Properti Dengan Sistem. Widya.

Putra, F. M. (2019). Urgensi Batasan Atau Pengendalian Asas Kebebasan Berkontrak Pada Peristiwa Pre Project Selling. Jurnal Persektif, Volume 21, Nomor 1.

Raffles. (2010). Pengaturan Dan Model Alternatif Penyelesaian Sengketa Dalam PerundangUndangan Indonesia. Inovatif, Jurnal Ilmu Hukum, Vol. 2 No.3.

Salim, N., \& Pandamdari, E. (2019). Tanggung Jawab Developer Terhadap Konsumen Akibat Wanprestasi Dalam Penyerahan Unit Apartemen Pluit Sea View Berdasarkan Perjanjian Pengikatan Jual Beli. Jurnal Hukum Adigama, Volume 2 Nomor 2.

Yuliana, Asnah. (2018). Teori Abraham Maslow dalam Analisa Kebutuhan Pemustaka. Libraria, Vol. 6. No. 2.

Suparji, \& Pratamalistya, A. P. (2020). Kredit Kepemilikan Rumah Dalam Perspektif Hukum Perlindungan Konsumen. Jurnal Magister Hukum Universitas Al Azhar Indonesia, Vo. 1, No. 1, 1.
Udiana, M. (2011). Kedudukan dan Kewenangan Pengadilan Hubungan Industrial. Denpasar: Udaya University Press.

\section{ARTIKEL ELEKTRONIK}

Agustining, \& Yusrizal. (n.d.). Tanggung Jawab Perusahaan Properti (Penjual) Dalam Pemasaran Perumahan Pola pre project selling. Jurnal Magister Kenotariatan Universitas Sumatera Utara, 18. Retrieved Mei 25, 2021, from mkn.usu.ac.id:

http://www.mkn.usu.ac.id

Halomoan , M., \& Sitong, D. (2016). Penerapan Penyelesaian Sengketa Di Banda Penyelesaian Sengketa Konsumen (BPSK) Untuk Mewujudkan Kepastian Hukum. 28. Retrieved from http://e-journal.uajy.ac.id/9695/

\section{PERATURAN PERUNDANG- UNDANGAN}

Undang - Undang Nomor 8 Tahun 1999 tentang Perlindungan Konsumen.

Undang-undang Nomor 30 Tahun 1999 tentang Arbitrase dan Alternatif Penyelesaian Sengketa.

Undang - Undang Nomor 1 Tahun 2011 tentang Perumahan dan Kawasan Pemukiman.

Undang - Undang No. 20 Tahun 2011 tentang Rumah Susun.

Surat Keputusan Menperindag Nomor 350/MPP/Kep/12/2001 tanggal 10 Desember 2001 tentanga Pelaksanaan Tugas dan Wewenang Badan Penyelesaian Sengketa Konsumen (BPSK). 